\section{B A Institute of \\ YK Business Administration \\ 六下 \\ Karachi \\ Leadership and Ideas for Tomorrow}

Business Review

Volume 6 Issue 2 July-December 2011

7-1-2011

\title{
Succession in family businesses: Kinship culture and Islamic law of inheritance
}

Nasir Afghan

Institute of Business Administration, Karachi, Pakistan

Follow this and additional works at: https://ir.iba.edu.pk/businessreview

Part of the Business Law, Public Responsibility, and Ethics Commons, Islamic Studies Commons, and the Jurisprudence Commons

(c) (;)

This work is licensed under a Creative Commons Attribution 4.0 International License.

\section{Recommended Citation}

Afghan, N. (2011). Succession in family businesses: Kinship culture and Islamic law of inheritance. Business Review, 6(2), 104-118. Retrieved from https://doi.org/10.54784/1990-6587.1197

This article is brought to you by iRepository for open access under the Creative Commons Attribution 4.0 License and is available at https://ir.iba.edu.pk/businessreview/vol6/iss2/9. For more information, please contact irepository@iba.edu.pk. 


\title{
CASE STUDY
}

\section{Succession In Family Businesses: Kinship Culture And Islamic Law Of Inheritance}

\author{
Nasir Afghan \\ Institute of Business Adminsistration, Karachi, Pakistan
}

Keywords: Succession, Family Businesses, Kinship Culture, Islamic Inheritance Law.

\section{Introduction}

Majority of research has been carried out on succession within family firms in the positivistic tradition of research and also has a very strong normative element to it. The successful research has been defined using researchers determined criterion such as firm performance, viability and harmony among the family members etc. This type of research obviously assumes an independent reality 'out there' ready to be collected by objective researcher. This positive stance has been apparent even in the case based research mostly conducted by practitioners. On the contrary, to carry out this research an interpretive approach was adopted. The aim of interpretive research is to understand the social actions of human agents on the basis of meanings these agents attached to actions. The meanings are subjective and have to be understood from the agent's perspective. In succession within family business, what are the 'ideals' of succession process in terms of when a child should be inducted into the business and when should he be given the ownership and full control (if it should be given at all) is a highly subjective issue. What is 'success' itself is a highly subjective issue. Is it profit, family harmony or something else? And then what is 'family harmony' again is a subjective matter and its definition will vary across people. Succession process within a family business will be influenced by family members' interpretive schemes including their conceptions of rules of "rights and wrongs". In order to understand and explain the succession process within a family firm, it is believed that it is very important to understand these interpretive schemes and rules. These interpretive schemes are influenced by culture of the place. Culture which appears and hit individuals like an objective reality itself emerge from subjective understanding objectified through human interaction. Objective of this research has predominantly been to describe the succession process from successors point of view e.g. (Longenecker and Schoen, 1978; Handler, 1994; Sharma, Chrisman \& Chua, 2003).

\section{Details of the problem}

No prior literature is available on succession process within Pakistan. Pakistan, a country of 165 million people is the fifth largest country in the world. Located in South Asia, it has an area of roughly eight hundred thousand square kilometer. The objective of this research is to explore and explain family business succession process within Pakistani culture. Pakistani culture is a kinship culture which means a collective culture where there is a "preference for a tightly knit social network in which individuals can expect their relatives to look after them in exchange for unquestioning loyalty"(Hofstede, 1984). However, there is a lot more in Pakistani culture than what could be described by Hofstede, obviously 
because of his methodological limitation. Using a case based approach, we intend to understand the values, beliefs, norms and mindsets of a particular business family and will then try and explain the succession process utilizing these understandings.

The knowledge and understanding generated in this research will provide insights into succession process within kinship culture based family businesses. Therefore, following objectives were set for this exploratory research. The first was to compare the succession dynamics of locally managed family businesses, grounded in the local cultural and religious environment, with the academic research conducted in other parts of the world. This was to validate the already developed empirical knowledge. The second objective was to investigate succession dynamics of the family businesses in Pakistan, since the majority of the family businesses are facing succession challenges from founder generation to second and third generation of successors

It is expected that this research would be useful to provide answers to several interesting questions. Following questions were posed to provide in-depth insights into the succession process within the Pakistani culture. What elements and norms of Pakistani culture influence succession during the succession process? And what are the mindsets, the values and norms perceptions and behaviors that are shaping and creating succession reality for succes sors and family members? How each successor perceives and desires successful succession of the business? Would it be unity of the business or the harmony among the family members or are both desirable? What they see as key factors for successful succession process and why have they had those perceptions? How would they go about deciding distribution of shares in the businesses among family members? How would be the interpersonal relations within the family and business before, during and after the succession? Are there any linkages between Islamic inheritance laws and the succession practices? How would family manage the post succession phase? Would it be separate ways for each family member, and potential for rivalry among family members? Would they be working as large business group etc? The findings would provide insights into the succession process within the kinship culture prevailing in Pakistani society.

Since, approximately $80 \%$ of employment within Pakistan is generated by family businesses; therefore, well-being and continued growth of these family businesses is important for a developing country like Pakistan. Hence, knowledge and understanding generated in this research will provide additional insights into successful succession and successor development. To achieve these objectives, a literature on succession within the family business was conducted. Literature on kinship culture, local Pakistani cultural norms and Islamic inheritance laws was rese arched to develop understanding with respect to succession within the family businesses. Successful succession was defined from literature research and compared with the empirical case study research.

\section{Succession within the family business: literature review}

In reviewing the literature on family firms aim has been to identify succession practices that family firms adopt in their successful succession. Research on family firms in South East Asia and the Middle East is rare and our literature review primarily reveals Western theoretical frameworks. This paper constitutes the extent of applicability of the theoretical framew orks on the Pakistani socio-cultural and religious environment. Succession is viewed by many scholars as a long-term process involving multiple activities (Handler, 1994, 2004; Sharma, Chrisman \& Chua, 2003). Longenecker and Schoen (1978), for instance, 
have pointed out that a successor's training takes place throughout childhood, adolescence and adult years. Their basic proposition is as follows: 'Parent-child succession in the leadership of a family-controlled business involves a long-term diachronic process of socialization, that is, family successors are gradually prepared for leadership through a lifetime of learning experience' (Longenecker and Schoen, 1978, pg. 1). One critical activity that entails the succession process is the grooming of the future leader of the firm (Fiegener, Brown, Prince \& File, 1996; Sharma, Chrisman \& Chua, 2003) which ensures that the successor is skillful and experienced enough to take over the business. Foster (1995) cites developing leadership in the successor generation as crucial to the survival of family-owned and family-managed businesses. Ward (1987), in his study of 200 family businesses, found that successor development was one of the most important characteristics associated with businesses that were able to survive a generational transition (Lansberg \& Astrachan, 1994). Stavrou's (1998) presented succession model of pre-entry, entry and succession phases. The pre-entry stage represents the time when the successor is not a full time working member of the firm but is involved through family discussions and part time employment. The entry stage represents the time period when the successor joins as a full time employee and is integrated into the firm. The succession stage occurs when the successor is ready to take over the business as the future leader and the founder-owner is nearing retirement or moves to an advisory position. For this study we would only be focusing on the succession phase activities and comparing those with the literature findings. Considering the significance attached to successful succession, it is important to establish what constitutes effective succession. Research by Churchill and Hatten (1987) measured effective succession by "incumbent's ability to increase revenues and profits in their organizations" (Goldberg, 1996). Apart from monetary measures, Friedman $(1984,1986)$ specifies the company's reputation, turnover and the succession process as being relevant (Goldberg, 1996). Maintaining business unity is another factor that measures successful succession since the continuity of the family business as a single entity is important for successful succession. Since it is assumed that an effective success or leads the family firm lucratively, successful succession is measured in terms of increase in profitability and growth and unity of the family business.

I"igne I

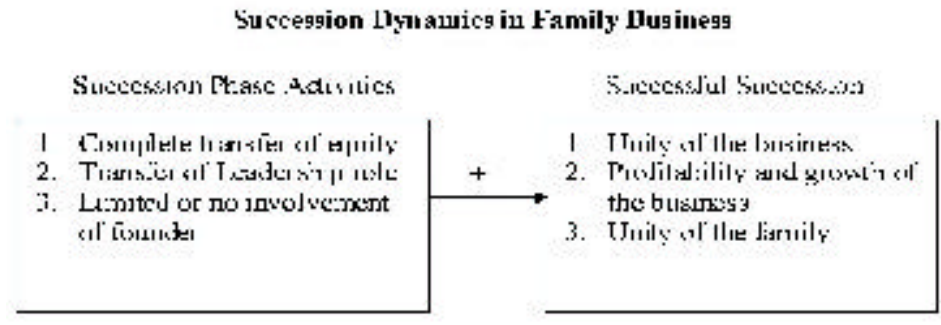

Literature survey also provides definitions of successful family busines s and succession:

1. The subsequent positive performance of the businesses and ultimate viability of the businesses. (Miller, 2004).

2. The satisfaction of the stakeholders with the succession process (Cabrea-Suarez et al.,2001; Dyer, 1986; Miller, et al., (2004); Handler, 1990; Morrise et al.,1996; Sharma et al., 2001, 2004) 
3. The company's reputation, turnover and the succession process as being relevant (Goldberg, 1996)

4. They experience profitable business as well as family harmony. In other words, they enjoy high cumulative stocks of both financial and emotional capital that may help sustain the family and business through turbulent economic and emotional times (Sharma, 2004)

\section{Succession phase activities}

During the succession phase, an important method of continuing the development of the successor is to transfer all the leadership responsibilities onto him that once belonged to his father. This is necessary for a smooth transition once the successor has been sufficiently prepared. Longenecker and Schoen (1978) suggest that it takes at least two years to 'master the complexities of the position and gain the control as sociated with the leadership role' (p.5)'. Along with the transfer of roles from successor to leader, decision making power, authority and equity are transferred simultaneously (Handler, 1994, pg. 151). It is also essential that once the successor has been effectively integrated into the family firm and becomes self-sufficient, it is necessary for the founder to lessen his involvement. Dyer (1986) believes that to allow successful succession to take place, the founder should gradually move away from active involvement in the firm's operations (Handler, 1994, pg. 149). According to Lansberg (1988) "the boundaries around the founder's involvement to be drawn very clearly and for both the founder and the successor to monitor this aspect of the transition carefully" (pg. 136). The reason for this is that it is often hard for the founder to leave the family firm after having managed it for years, and as a result may 'infringe on the succes sor's territory and autonomy' (Lansberg, 1988, pg. 136). Another important step that aids successor development is the transfer of equity in the successor's name. Sharing the ownership of the firm encourages successor interest and commitment to the firm. Equity transfer normally takes place when the successor assumes the CEO position. According to Barach and Ganitsky (1995) 'a successful succession is most easily accomplished when the planned or actual disposition of stock parallels the transfer of power' (pg. 143) and as per Handler (1994), one sign of an effective succession is control of the stock by the next generation. Therefore for the succession phase we propose that transferal of leadership responsibilities, curbing the founder's involvement and full transferal of business equity are positively associated with the successful succession.

\section{Understanding the local culture}

A complete understanding of any subject entails examining the context within which it is embedded. Therefore, in order to gain a deeper understanding of successor development and succession within family firms of Pakistan, we must consider the sociocultural and religious environment in which they operate. Howorth and Ali's (2001) examination of case studies in the furniture industry of Portugal looks at family business succession from a cultural perspective, and proves useful for our research since it indicates that 'culture and ethnicity are fundamental to a family firm's operations and motivations' (pg. 231) and specific aspects of culture are expected to effect each strand of the framework (pg. 241).

According to Ward (2000) 'national culture is a distinguishing influence on the family that shapes a business family's ownership and leadership vision' (pg. 272). Similarly, 
Hofstede (1984) states that people build organizations according to their values and societies are composed of institutions and organizations that reflect the dominant values within their culture (1984). It is useful to understand the definition of 'culture' before reviewing the case of the Pakistani family firm environment. Hoecklin (1996) defines culture as a collective phenomenon that is about shared values and meanings. According to Hofstede (1984) 'culture consists of the patterns of thinking that parents transfer to their children, teachers to their students, friends to their friends, leaders to their followers, and followers to their leaders'. Pakistani culture can be described as collectivist, highly power distant and masculine. A collectivist culture is one where there is a 'preference for a tightly knit social framework in which individuals can expect their relatives, clan, or other in-groups to look after them in exchange for unquestioning loyalty' (Hofstede, 1984). Collectivism applies in Pakistan because the primary social organization in the country is a web of kinship networks or biradari (kinship) as it is called in Urdu, the national language of Pakistan. The concept of biradari (kinship) extends beyond the immediate family of an individual to include one's own cousins and those of the parents as well. According to Stanley Kochanek, 'the individual in Pakistan is tightly knit into a well-structured kinship network which determines his status, mobility, and success' (1983). Cross-cousin marriages within the biradari (kinship) not only strengthen family ties but also reinforce the financial foundations 'by retaining land and property within the family' (Kochanek, 1983). Another important factor that strengthens and unifies the biradari (kinship) is a sense of loyalty and respect for the norms of that group. 'One such norm is the need for providing for the economic wellbeing of members of the biradari (kinship). In practice, therefore, many of those hired are members of a family' (Ansari and Bell, 1991). Members of the biradari (kinship) are mutually obligated to support each other in feuds and conflicts regardless of the justice of the issues involved, and those in position of authority are expected to favor those who are not (Kochanek, 1983). Due to the adherence of these norms, a high level of trust or bharosa (trust) exists between the biradari (kinship) members, which create further solidarity. Power distance refers to the 'extent to which inequality (hierarchy) is seen as an irreducible fact of life' (Hoecklin, 1996). Whether a culture is low power distant or high power distant depends on the level of inequality and empowerment that exists in relationships. Pakistani culture is characterized by high power distance because the structure of organizations is hierarchical and power is typically centralized. Families, too, support a structure of hierarchy with the father being the head of the family and the eldest son having more say in decision making than the younger ones. Children are expected to respect and obey their parents and refrain from questioning their authority. The elders of the families, or buzurg (elderly), such as paternal or maternal grandparents or great grandparents are also considered wise and experienced and are to be treated with respect and reverence. Sibling rivalry is discouraged and siblings are instructed to respect each other from an early age. The elder brother is referred to as bhai (brother) in Urdu which literally means brother. This 'is not a symbol of equality but a mark of respect for family hierarchy' (Ansari and Bell, 1991). Masculinity 'stands for a preference in society for achievement, heroism, assertiveness, and material success' (Hofstede, 1984). A masculine society can be described as one in which there is maximum difference between the social roles of the sexes. 'The norm is then that men are given the more outgoing, assertive roles and women the caring, nurturing roles' (Hofstede, 1984). The polarity of roles assigned to or expected of the majority of men and women in Pakistan indicates that the indigenous culture is essentially masculine. The sons of the family are expected to act responsibly and to assume leadership when the time arrives, and the daughters are expected to be married off and honorably start a new life in a new home. Men are regarded as the bread- winners of the family and women are expected to nurture the home and the children. The kinship and hierarchical nature of the society inculcates status-consciousness in the 
minds of the people. Status is closely tied to the concept of izzat (honor) which can be translated as honor, prestige and privilege (Kochanek, 1983). The maintenance of a family or biradari's izzat (kinship's honor) is considered extremely important. It takes precedence over all other matters and cannot be compromised.

\section{Islamic inheritance law}

Pakistan was created on the notion of a separate Muslim state where the citizens would be able to freely profess and practice their religion. Since the majority of the population of the country is Sunni Muslim, there is a great degree of overlap between the Pakistani culture and the Islamic religion. The traditions of submission to authority, familial piety and bipolar social roles which have been previously explained through a cultural viewpoint are also recurrent themes in Islamic literature. Islam is not only meant as a religion but also as a way of life, which is why it provides injunctions and commands pertaining to all aspects of life to guide human beings in the right direction. One of the fields in which detailed legal guidance has been provided is that of inheritance. According to Athar Husain, member of the Board of Research of the Indian Institute of Islamic Studies, 'the rules regulating inheritance are based on the principle that the deceased's property should devolve on those who by reason of consanguinity or affinity have the strongest claim to be benefited by it and in proportion to the strength of such claim' (Husain, 2006, pg. 1). It is also in line with the principle of wealth distribution in Islam, which discourages the concentration of wealth within a single family or person or group of people. Although the law of inheritance is interpreted in different ways by the Sunnis and Shias, the rights of inheritance of the children stand. The male (son) gets twice the share of the female (daughter). It is important to note that the inheritance law is enforceable only upon the death of a person, and no law exists that overlooks the division of wealth before his demise. Father/owner of business can transfer wealth or equity to successors during his lifetime as a gift or hiba (gift) without any religious implications. An Islamic scholar Sheikh Kamaluddin Ahmad said that division of wealth is to take place within the lifetime of the father then it should be done according to the spirit of Islamic law; this basically means that the division of personal wealth ought not to deviate too greatly from that which has been prescribed by the law of inheritance so that the rights of the heirs, whoever they may be, are not violated. Moreover, no discrimination ought to take place on the basis of gender. If a daughter is working in the family business then she too is entitled to a share of the business equity if it is being transferred into the children's name. If the daughter is not involved in the day-to-day operations of the businesses she will have no claims on her father's business assets. However, she would have a claim if her father died without dividing the business assets or if the father had a business share which was owned and managed by him alone.

\section{Research approach}

Research projects that involve studying of mindsets, beliefs and values of people and how this perceptual grasp of people affects the day to day actions inevitably require a closer engagement with the field. The focus of this research is discourse of succession process therefore the grounded theory approach suited the most. In grounded approach, theories are drawn from the field data and are likely to offer insight, enhance understanding, and provide a meaningful guide to action (Glaser \& Strauss, 1967). According to Isabelle (1990) grounded approach requires that data and theory be constantly compared and contrasted through the data collection and analysis phase. Emerging theory directs attention towards the previously established important dimensions. Hence, the interplay between data 
and theory provides an interesting insights and possibility of reconceptualization of the old theory and new understanding.

According to Chua (1986) "[In interpretive research] "thick" case studies conducted in the life-world of actors are preferred to distant large-scale sampling or mathematical modeling of human intention". Since the research project involves study of minds ets, beliefs and values of people therefore Eisenhardt (1989) case study approach was used for the purpose because it fits in with the research objective.

The selected business case which is a fan manufacturing firm has a long history in manufacturing and craftsmanship. The business founders were brass pots craftsman and in 1965 they set up small factory to manufacture fans. In 2006, one of the selected firm was the second largest fan manufacturing company in Pakistan, with total production around 900,000 fans per year (see figure 2.0 for family tree). Moreover, the selected firm is the part of kinship (Mughal Biradari) or extended family system. This particular kinship or extended family owns almost $90 \%$ of the fan manufacturing in Pakistan. The selected firm has seen one succession since 1965. Initially, the business had three founders and after the death of the one of the key founder Muhammad Yunus in 1980 the other two founders and two sons of the late founder decided to split the businesses. Interviews were conducted with all three family members and their views on succession phase activities and perception about succession processes are recorded. Interviews are also conducted to have their point of view on culture values, norms, and inheritance practices.

Figure 2.0: provide a classic family genealogy of Mughal Biradari and respective fan company including Yunus Fans and GFC Fans, etc.

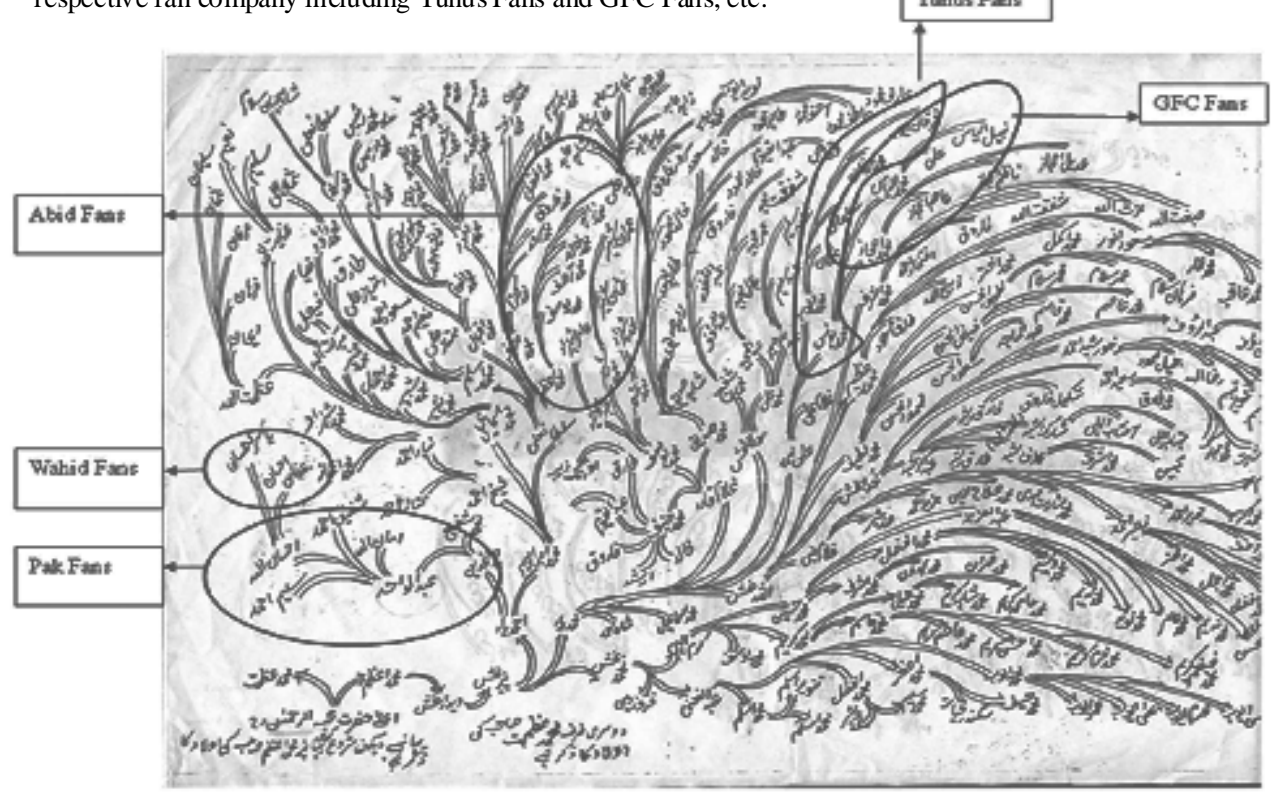

The literature survey provided an understanding of succession in family businesses in general. Since the empirical research on family businesses in general and succession in particular in this part of the world has never been done, the in-depth case study approach was deemed most suitable for this study. The generalization from this research is mainly 
'analytical generalization' (Yin, 1994). According to Yin (1994) 'a case study is an empirical inquiry that investigates a contemporary phenomenon within its real life context, especially when the phenomenon under study is not readily distinguishable'. Since the study of kinship culture and Islamic law is a part of this study, it created a technical challenge due, first, to the complexity of the local culture and second, to a lack of a clear boundary between religious and cultural practice. No proposition regarding influence of cultural and Islamic inheritance laws and successful succession activities were developed, it was decided let the research process provide elements of culture and successful succession from the family member's point of view.

Another challenge was collecting information from multiple sources therefore we conducted detailed semi structured interviews with the father/owner and the successor in all three branches of the family businesses. Apart from the interviews, reports and records of organizational history related to succession of published companies were also collected and used during the case writing process. After the research a case study report was generated and was shared with the respondents to get their approval on the observations and findings. Validity was achieved through interviews with multiple sources (father, son or other successors in the family business) for the same set of variables. The initial case study findings were also shared with the key respondents for data validity and reliability. In the following section case studies provide insights into the dynamics of successor development and succession in the local organizational and cultural setting.

\section{Case study - General Fan Company (GFC)}

\section{Pre succession phase}

General Fan Company was established in 1954 as a private limited company by a group of twelve partners to manufacture and supply fans to the local market. In the late 1970s, however, differences among the partners started to arise with some of them entering into direct competition with GFC by starting their own separate manufacturing lines. By 1978 the differences among the partners had become so vast that production in the factory was stopped. Finally the partners decided to sell the factory; which was then acquired by Yunus Industry in 1978.

Yunus Industry was established in 1963 by Muhammad Yunus with his brother Mohammed Ayub and brother in law Mirza Anayat Ullah. They started manufacturing fans under the brand name Yunus Fans. The share distribution was 50\% with Muhammad Yunus and 25\% each for Muhammad Ayub for Mirza Anayat Ullah (brother in law).

Muhammad Yunus established three businesses in his lifetime: Yunus Industry, GFC and Metro Fan Industry. Upon acquiring the factory in 1978, Muhammad Yunus decided to keep the brand name because GFC Fans had been able to develop some brand equity in the markets of Multan and Faisalabad. He gave his son Muhammad Ilyas the responsibility of running GFC as CEO. In 1980 Muhammad Yunus died and the Yunas group started to work together but the differences started to emerge in mid 1980s among partners. According to Muhammad Ilyas "I wanted to buy some new machinery as my production was growing but other partners did not allow me. It was difficult for me to stay within the same group". 


\section{During succession phase}

In 1998 M. Ilyas (son of Mr M Yunus) and Mohammed Ayub and Mr Mirza Anayat Ullah started thinking of having separate businesses for each family. Since M Ilyas was managing GFC, all decided that he should take GFC. M Ilyas's brother, M Ijaz also joined him as his partner. In 1999, Yunus Fans and Metro Fans split up again and Muhammad Ayub paid Rs. 50 Million to Mirza Anayat Ullah for the brand equity of the Yunus Fans. These split ups were cordial and were 'necessitated' in order to avoid the consequences of internal conflicts that were faced by other companies. According to one family member "We all knew the shares of each family and we also knew the areas of specialization within the business of each family. Like for example Muhammad Ilyas and his brother families were in the GFC therefore GFC should go to the m. We started listing all the material, receivables, inventories at their values (in Rs). Each family picked up the factory they were working and every single item was on the board. After splitting the businesses, we decided to look at the cash in bank and banks ODs we divided among families". Since, businesses were established on the basis of partnerships and percentage shares, therefore legally it was possible to give each branch of the family its shares or the portion of the businesses during the division.GFC was jointly owned by Muhammad Yunus two sons and they owned $50 \%$ each.

\section{Post succession}

Mirza Anayat Ullah's sons in Metro Fan started manufacturing Metro motorcycles in early 2000. Metro fan industry is successful in moving business into new indus tries and takes advantages of the engineering background and the knowledge. Muhammad Ayub family in Yunus Fan also decided to export fans to the Middle East. All three companies are enjoying growth in the businesses after the secession.

The annual sale of the GFC, now a group was is Rs. 398,580,555 in the year 200506 and employs 600-700 (due to the seasonality factor). GFC group has its production facility and headquarter located in Gujarat, Pakistan's 6th largest business hub. They have started GFC washing machine and other GFC products. They also started exporting GFC fans to more than 12 countries in the world.

All three business families still live in the same compound called Yunus Abad developed by M. Yunus in 1970s. The three families enjoy joint family dinners and intermarriages are common. Mr Ilyas takes daily morning walks with the heads of these business families and discusses his strategies for new opportunities in the export business.

Succession not only helped each business to grow and develop a new strategy and move into new areas but also improve the harmony among family members. According to M Ilyas (CEO of GFC) "The main thing is that we should be able to manage our business as we want our own strategy and our own implementation plan. If there are many partners, every partner would like to manage it according to his thinking. Secondly during the succession one should not worry about Rs.2 or 3 millions, it is possible that some family member will have more than his share, since we are one biradari and family, it is okay. We must keep good relations with all family members". All the three families have excellent relations with each other. They still practice inter marriages and are part of each other's social life. The families even help each other in business and the sharing of knowledge. Succession within the kinship provided not only growth in the business but also harmony 
among the families and partners.

In 2005 Mohammad Nabeel Ilyas, son of Mohammad Ilyas, joined GFC as the entrusted successor of the company (See Exhibit 1). Nabeel currently overlooks and is involved in all operations of every department of the company. His father has not transferred any equity to his name and has not delegated the overall leadership to him as yet.

\section{Discussions}

The businesses in case studies did well in the financial performance indicator and business was growing more than $10 \%$ in revenue and more then $7 \%$ in profitability since the last succession. At GFC Muhammad Ilyas CEO has $50 \%$ (equity) ownership of the business with the remaining $50 \%$ owned by his brother. Muhammad Ilyas wants to divide the business between his brother and his own two sons, but the successor (CEO son) refused to accept the division of the business. The successor (Muhammad Nabeel) wants to keep the business united and wanted to distribute the shares in the business to the next generation of successors. Muhammad Ilyas, from his own experience, wanted to set up different businesses for his two sons and for his brother family (and his sons), as his father (Mohammad Yunus) had done during his life. Muhammad Ilyas said "Because during the first succession Yunus group was divided among partners, therefore, during the second succession it is expected that GFC group will be divided among partners". However, there was no equity transferred to daughters and daughters were not expected to working in the family business. During the course of our research on family businesses, we observed that during the succession phase (transfer of management and control from one generation to the next) most of the family businesses were divided among family members and after each succession they were much smaller businesses in size and scope. Following section provides analysis of the influence of Islamic Inheritance law during the succession phase.

\section{Islamic inheritance law}

In Pakistan, Muslim family laws are applied for inheritance, and the division of wealth and property. If any family member within the business desires to go separate ways these rules are applied and therefore the division of the businesses. To determine the application of the Islamic inheritance law in family business succession, we asked the respondents during the case research if they had used Islamic law during the succession or transfer of equity or ownership to the next generation of successor. Study showed that none of the family had any women in the business operations, and there was no share in the business for their daughters. Daughters were married within the family to cousins and were given furniture, jewelry or cash (dowry) at the time of the wedding. The business assets were divided among sons on an equal basis by the father/owner in his own life. In the case study, the father's sudden death prevented the division of the assets of the business amongst the successors. Therefore, the sons and brothers of Mohammad Younus divided the business units among themselves, with the help of buzurg (elderly) of the biradari (kinship). This division of business consequently included the division of business equity, fixed assets, employees, cash, products and even the furniture. Therefore, the study observed that family businesses adhere to Islamic inheritance laws during the succession phase and in the division of business assets among the successors. Consequently Islamic inheritance laws and the practice, both influence the division of the businesses during the succession phase. 


\section{Kinship culture}

To determine the practice of kinship culture and its influence on business succession we asked the family heads and other members regarding their biradari (kinship) system, norms and values, and whether the family had any preference towards having a central figure or practice of family council/board or rational and a systematic process of decision making. The respondents were strongly in favor of respecting and following biradari (kinship) values and norms. This was supported from the history of the organization. As it has already been mentioned, in a biradari (kinship) sys tem one of the norms is trust between members of the biradari (kinship). Therefore, major investments and new startups are taken up jointly by biradari (kinship) members, and financial positions within the business would also go to them. Muhammad Yunus started his first fan factory with the financial and human support from his brothers. This means that when it comes to providing jobs in the business, the biradari (kinship) members will be the first choice for recruitment, because of trust and loyalty, regardless of merit and competence.

It was observed in the case study that business founders turned to brothers and family members to help them in times of setting up the new business or business expansion. Regardless of their experience and educational background and business inclinations, family members were included in the business. Another concept that has been previously explained is the concept of bhai (brother) or buzurg (elderly) (elder brother or father figure respectively). Bhai in the biradari (kinship) system has authority and decision making powers and everyone in the family accepts his decisions unquestioningly since it is assumed that his decisions will respect the interests of the members. The family businesses depended very much on single family member for all operational and people related decisions. Founder rarely transfer any decision making powers to professional staff. Such a scenario is similar to other Islamic countries; for example in the family companies of the Gulf Region, the elder brother or father figure has overwhelming authority and "regardless of talent, the eldest male is generally given the business leadership role, even if another family member might be better suited for the job" (Davis et. al, 2000, pg. 231). Case Study showed strong respect towards the Muhammad Yunus as key figure in all business and personal decisions. Muhammad Yunus was the person deciding all the future investment in the businesses, and perhaps he was the most entrepreneurial among all. In the case of GFC, Muhammad Ilyas was playing the leadership role.

Moreover, according to one of the interviewee, Muhammad Yunus showed respect for family unity and harmony and for him conflicts between siblings and cousins was seen as a sign of losing izzat (honor) (losing face) which is considered the ultimate disgrace and therefore should be avoided. To further enhance family bonding, the practice of inter-family marriages was encouraged. Hence, the biradari (kinship) system played a major role by providing trustworthy support and investment in the formation of business in its early phases and in centralized decision making by the family head. Muhammad Yunus purchased a big land in 1972 and build three houses, one house for each partner's family. All three families still live in the same big compound even after the division of the businesses.

It was surprising to observe that despite the strong kinship bounding among family members at every succession phase, businesses were divided among successors, partners and brothers, sons etc. During the second round of interviews it was observed that within the Kinship culture (biradari) one of the most common social norm is Shareeqah (rivalry among cousins). It is perceived fear that the other brother or cousin will perform better and 
get ahead in the business. This rivalry is not only for financial resources, material wealth but also for status and position in the society and linkages with civil and political elite. In case of first succession Muhammad Ilyas said "Because of Shareeqah (rivalry among cousins) I decided to separate from the Yunus group". The similar arguments were presented by other family members during the interviews. Normally Shareeqah (rivalry among cousins) begins when there is unfair distribution of land, other property and wealth among brothers (father's land and wealth etc) and this competition can continue for generations. The Shareeqah (rivalry among cousins) does create an environment of mistrust and fear among family members. Junior and less competent or less educated member fear that more senior or competent family member is taking over businesses and other key resources of the business. Hence, some family member view that it is better if there is a current.division of the business. In the case of GFC present CEO was planning to separate his part of the businesses from his brother's family due to future possibility of Shareeqah (rivalry among cousins) between his children and his brother's children.

Moreover, family elders do consider the division option and build different factories and businesses as independent operating units and on right time, each family (sons, siblings and partners etc) could take over one independent business. Also founders provide a chance to each son and his family to develop skills and knowledge within one type of the businesses. Thus they encourage specialization of each family (son) and therefore natural basis for future division within the business.

Hence, the objective of family harmony and intermarriages is achieved over unity of the business. It was also observed the successful succession meant fair and just division of business and family harmony. The inheritance laws regarding division of wealth and land and property were strongly followed since it provides family members chance to have their own business regardless of its size and scope.

The concept of complete ownership without interference and claim from other family member was perhaps the most desirable objective of the succession process. Moreover, due to internal competiveness and Shareeqah (rivalry among cousins) (each owner of the business, son or brother) businesses continue to innovate and diversify into new businesses. The success of this new enterprise would depend on his competencies as a business person, his hard work, luck and his abilities to turn small business into big success and establish new businesses.

It is interesting to note that even when there is tough competition among family members on financial, businesses and other resources they continue to enjoy intermarriages within the same families. There would be tension between the family members during the negotiations and division of the business phase but once it is over and settled, they pick the family relations and family ties where they had left. It is also because of intermarriages and influence of women in keeping the family relationships.

Also once the business divisions have been implemented family members and brothers do provide financial and other resources to other family member for establishing new businesses. Provided they have confidence over his success. Therefore, it can be safely concluded that if the family has strong preference towards kinship culture and there is Shareeqah (rivalry among cousins), it will positively influence the division of the family business assets and consequently division of the business. 


\section{Conclusion}

During the succession phase activities transferring equity and leadership roles were considered less important and were delayed until the final succession or until the division of the business. Moreover, role adjustments of successor and father during the succession phase were considered less important and the father's presence was considered a blessing. The influence of kinship cultural norms such as Share eqah (rivalry among cousins) was influencing as intervening variable within family businesses succession and eventually causing the division of the business during the succession phase. A successful succession within the family business is to have the family harmony and distribution of rightful share to other family members rather than keeping the business united.

Kinship culture based family businesses continue (ultimate viability of the businesses) to exist as businesses after the succession from one generation to the next generation but rather small and divided. Kinship based businesses provide excellent opportunity for grooming and developing future business leaders. Young successors get good exposure to different role models in the family. They also get early experience of managing the business, have social capital, and develop business acumen which would be useful in future. Kinship based family businesses have access to financial and business capital, which essentially help in cyclic business performance.

\section{Limitations and future research}

One case study has perhaps it's clear limitations; due to limited resources available for this research we could not cover more cases. It would be desirable in the future to investigate family business succession and transformation from the insights provided in the present research. 㞷彞

\section{Exhiblit: 1.0}

\section{FAMILY TREE FOR YUNUS GROUP}

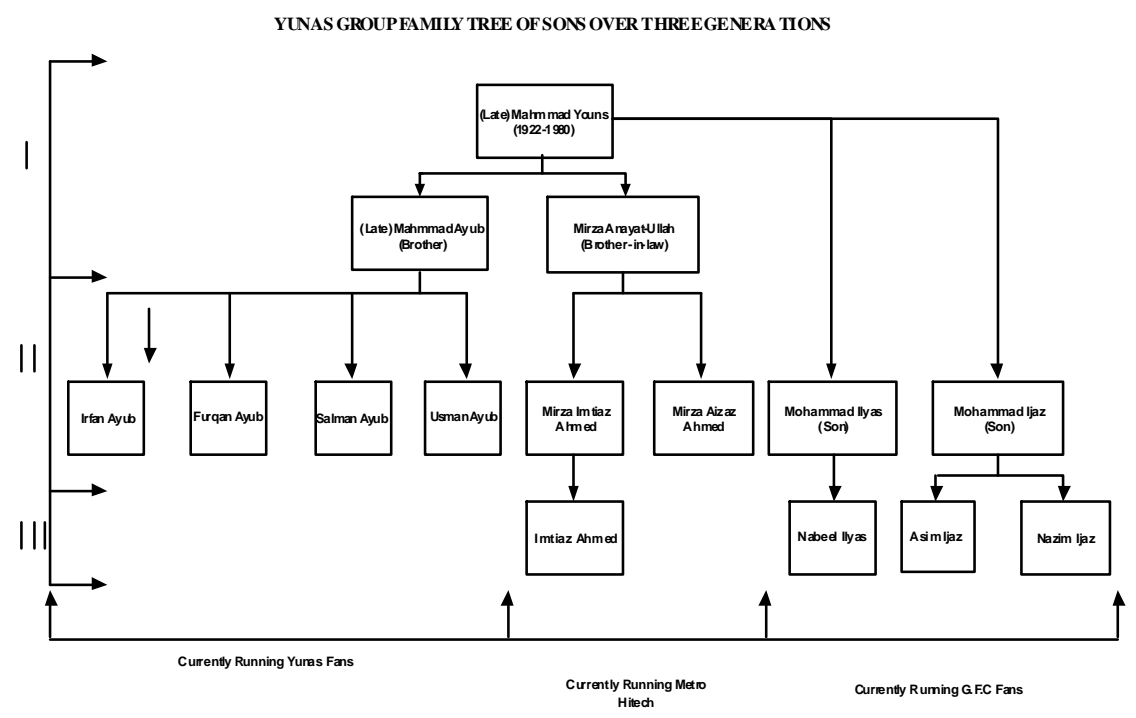




\section{References}

Ansari, S.L., and Bell, J. (1991). Symbolism, Collectivism and Rationality in Organis ational Control, Accounting, Auditing \& Accountability Journal, 4(2), 4-27.

Barach, J.A., and Ganitsky, J.B. (1995), Successful Succession in Family Business, Family Business Review, 8(2), 131-155.

Cabrera-Suarez, K., Se Saa-Perez, P., and Garcia-Almeida, D. (2001), The Succession Process from a Resource- and Knowledge-Based View of the Family Firm, Family Business Review, 14(1), 37-48.

Davis, A. J., Pitts, L. E., and Cormier, K. (2000), Challenges Facing Family Companies in the Gulf Region, Family Business Review, 13(3), 217-238.

Dyer, W. Gibb., (2004), Culture and Continuity in Family Firms, Family Business Review, 1(1), 37-50.

Eisenhardt, K.M., (1989), Building Theories from Case Studies Research, The Academy of Management Review, Vol. 14, No. 4, 532-550.

Fiegener, M.K., Brown, B.M., Prince, R.A., and File, K.M. (1996), Passing on Strategic Vision. Journal of Small Business Management, 34(3), 15-26.

Foster, A.T. (1995), Developing Leadership in the Successor Generation. Family Business Review, 8(3), 201-209.

Goldberg, S.D. (1996), Research Note: Effective Successors in Family-Owned Businesses: Significant Elements, Family Business Review, 9(2), 185-197.

Handler, W.C. (1990), Succession in Family Firms: A Mutual Role Adjustment Between Entrepreneur and Next-generation Family Members, Entrepreneurship: Theory and Practice, 15(1), 37-51.

Handler, W.C. (1994), Succession in Family Business: A Review of the Research, Family Business Review, 7(2), 133-157.

Handler, W.C., (2004), The Succession Experience of the Next Generation, Family Business Review, 5(3), 283-307.

Handler, W.C. and Kram, E.K., (2004), Succession in Family Business: The Problem of Resistance. Family Business Review, 1(4), 361-381.

Hoecklin, L. (1996), Managing Cultural Differences: Strategies for Competitive Advantage. Addison-Wesley.

Hofstede, G. (1984), Cultural Dimensions in Management And Planning, Asia Pacific Journal of Management. 
Howorth, C., and Ali, A.Z. (2001), Family Succession in Portugal: An Examination of Case Studies in the Furniture Industry, Family Business Review, 14(3), 231-244.

Husain, A. 'Muslim Personal Law: An Exposition.' The Canadian Society of Muslims. 30 Nov. 2006. <http://muslim-canada.org/muspersonallaw12.html >

Isabella, L. A., (1999), Evolving Interpretation as a Change Unfolds: how

Managers Construe key Organizational Events, The Academy of Management Journal, Vol. 33, No. 1, 7-41.

Kochanek, S.A. (1983), Interest, Groups and Development: Business and Politics in Business. Karachi: Oxford University Press.

Lansberg, I.S. (1988), The Succession Conspiracy. Family Business Review, 1(2), 119-143.

Lansberg, I., and Astrachan, J.H. (1994), Influence of Family Relationships on Succession Planning and Training: The Importance of Mediating Factors. Family Business Review, 7(1), 39-59.

Longenecker, J.G., and Schoen, J.E. (1978), Management Succession in the Family Business, Journal of Small Business Management, 16(3), 1-6.

Miller, D., Steier, P., Lioyd., and Miller, L. Is abelle., (2003), Lost in time: intergenerational succession, change, and failure in family business, Journal of Business Venturing, 18 (2003) 513-531.

Miller, L. Is abelle., Miller, D., and Steier, P. Lioyd., (2004), Towards an Integrative Model of Effective FOB Succession, ENTREPRENEURSHIP THEORY and PRACTICE, Summer, 2004.

Morris, H. Michael., Williams., W. Roy., and Nel., Deon., (1996), Factors influencing family business succession, International Journal of Entrepreneurial Behavior \& Research, 2 (3), 68-81.

Sharma, P., Chrisman, J.J., and Chua, J.H. (2003). Succession Planning as Planned Behavior: Some Empirical Results. Family Business Review, 16(1), 1-15.

Sharma, P., (2004), An Overview of the Field of Family Business Studies: Current Status and Directions for the Future, Family Business Review, 17(1), 1-36.

Sharma, P., Irving, P. Gregory (2005), Four Bases of Family Business Successor Commitment: Antecedents and Consequences, ENTREPRENEURSHIP THEORY and PRACTICE, 29(1), 13-33.

Sharma, P., Chrisman, J.J., and Chua, H. Jess., (2003), Predictors of satisfaction with the succession process in family firms, Journal of Business Venturing, 18 (2003) 667-687. Stavrou, E.T. (1998), A Four Factor Model: A Guide to Planning Next Generation Involvement in the Family Firm, Family Business Review, 11(2), 135-142. 